\title{
JANU SANDHIGATAVATA: A COMPREHENSIVE REVIEW OF THE AYURVEDIC LITERATURE
}

\section{Ayurveda}

Dr. Biswajit Dash*

\section{Dr. Rabindranath Acharya}

Lecturer, Department of Panchakarma, Government Ayurvedic College, Balangir, Odisha. *Corresponding Author

Ex-Professor, Department of Panchakarma, SSN Ayurveda College \& Research Institute, Paikmal, Odisha

\section{ABSTRACT}

Janusandhigatavata is also correlated to Knee osteoarthritis due to resemblance in sign and symptoms i.e. joint pain, stiffness, muscle weakness, swelling of knee joint, deformed joint, reduced range of motion and loss of use of the joints and cracking sounds. When the vitiated vata lodges in janusandhi (knee joint) it is considered as Janusandhigatavata. In Ayurvedic classics Sandhigatavata is among eighty Nanatmaja Vata Vyadhi. The aetiopathogenesis, symptoms and treatment of Sandhigata vata is described under Vatavyadhi which is found in a very concise form.

Among joint disease, Osteoarthritis is often seen out of which the functional disability in the knee joint is incredibly common in elderly. The approaches in therapies mainly carried out are physiotherapy or pharmacological therapy, but these approaches are limited over time by their cost and/or side effects. It is characterized by pain, shiftiness with decreased range of motion in the knee joint which is very common complaint for many people. With the advancement in working pattern and age-factors has become prime cause for aggravation of Vata dosha, which does dhatukshaya (depletion of tissues) and Balakshaya (reduced strength). Knee joint is weight bearing, strongest and most important joint in the body. Movements at the knee joint are essential for all everyday activities, including walking, running, sitting and standing. Different modalities of treatment have been explained in the Ayurvedic classics to tackle the condition effectively. Here, an attempt has been made for a systematic review on this disease with an approach to Ayurvedic management.

\section{KEYWORDS}

Janu sandhigata vata, Pain, Osteoarthritis of Knee, Ayurvedic management

\section{INTRODUCTION}

The classical term 'Janu Sandhigata Vata' in Indian Medicine can be correlated with Osteoarthritis (OA) of the knee joint. It is one such chronic, degenerative, inflammatory disease which has a great impact on the quality of the life of an individual. The present day activities are prone to cause many life deteriorating conditions. Food, lifestyle and Environment are three important determinants related to the cause of disease. Sandhigatavata is one among the vatavyadhi ${ }^{1}$ and is the commonest form of articular disorder. Ayurvedic classics highlights degenerative diseases under the concepts of "Dhatu saithilya" and "Dhatu kshaya". Acharya Charaka described as 'Sandhigata Anila' in Vatavyadhi chiktsadhyaya.

The word 'Gata' is used to denote an initiation of a movement or carrying something along with or to reach a particular site through any particular pathway, that leads to occupancy at the particular site. Sama Dhatu Gati means normal metabolic transformation of tissues ${ }^{3 .}$ Being the most weight bearing joint, the knees commonly gets affected. The presentation of this pathogenesis is seen as Janu Sandhigata Vata. OA of knee joint comes under the inflammatory group which is almost identical to Sandhigata Vata described in Ayurveda with respect to etiology, pathology, and clinical features. Snehana and swedana are prescribed as common treatments in Vatavyadhi ${ }^{4}$. Also, Daha i.e. agnikarma, Swedana and upanaha are the main treatment of Sandhigatavata.

\section{Objective:}

The symptoms of Janu Sandhigata Vata vis-a-vis osteoarthritis of knee is where Janu refers to knee, sandhi is joint and Vata is the humour permeating the knee joint - in this with advancing age, the influence of Vata Dosha increases, resulting in the gradual degeneration of the body. A critical review of the disease with Ayurvedic therapeutics in the treatment and/or management of knee osteoarthritis. Specific emphasis is placed on interpreting the literature in the context of its strength and weakness with particular attention placed on study protocols used. Number of research works have been carried out to study the efficacy of treatment modalities in Janusandhigata Vata which is found in the AYUSH Research Portal and PubMed. The present article reviews the research work published. A unique study is made with relevant ayurvedic and contemporary science for future research. Here, relevant basic science is also emphasized.

Design: Literature Review

MATERIALS AND METHODS:

As the study is a review study, the available literature like the
Ayurvedic classics - the Samhita granthas, Sangrahas, Nighantus and other books are searched for the disease and treatment aspect of all the relevant content is considered and analyzed to get a comprehensive concept in the management of Janusandhigatavata (Knee osteoarthritis)

\section{Aetiology:}

In Kalaja factors, Shishira and Grishma (Summer) ritu are the major seasons where the patients get affected with the disease. Other factors like weakness during diseased state (Rogatikarshana) and injury to the marma sthanas (Marmaghata) ${ }^{5}$, emaciation (Dhatu Kshaya) etc are also considered as the causative factors for osteoarthritis, whereas Margavorodha comes under Vishesha Nidana. Common Hetus (etiological factors) of Vatavyadhi, which are mentioned by Acharya Charaka is shown in table 1.

Table-1 Showing Etiological Factors Of Vatavyadhi ${ }^{5}$ :

\begin{tabular}{|l|l|}
\hline AHARAJA & $\begin{array}{l}\text { Atiruksha (Excessive dry), Atisheeta (cold), } \\
\text { Atialpa (very less quantity), Atilaghu (very } \\
\text { light), Abhojana (no food intake) }\end{array}$ \\
\hline VIHARAJA & $\begin{array}{l}\text { Atiprajagarana (no sleep), Divasvapna } \\
\text { (sleeping in day), } \\
\text { Ativyavaya (excess sexual act), Vegasan dharana } \\
\text { (stopping natural urges), Plavana (swimming), } \\
\text { Atiadhva (excess walk), Ativyayama (excess } \\
\text { exercise) }\end{array}$ \\
\hline MANASIKA & $\begin{array}{l}\text { Atichinta (excess anxiety), Atishoka (excess } \\
\text { grief), Atikrodha(excess anger), Atibhaya. (fear) }\end{array}$ \\
\hline OTHERS & $\begin{array}{l}\text { Dhatunam Sankshayat, Rogatikarshanat } \\
\text { (weakness due to prolonged diseases), } \\
\text { Marmaghata (trauma to vital parts ) }\end{array}$ \\
\hline
\end{tabular}

\section{Clinical Features:}

The disease has no specific poorvaroopa. But the clinical signs and symptoms include joint pain (Sandhi vedana), Sandhi Shotha (Swelling), Vatapurna druti sparsha, pain and tenderness during the movements of the joints (Prasarana akunchana pravrutisavedana), cracking sounds (Atopa) and degeneration of the joint (Hanti sandhi).

Table 2: Risk Factors For Osteoarthritis ${ }^{6}$

\begin{tabular}{|l|l|}
\hline Risk factor & Effect \\
\hline Age & $\begin{array}{l}\text { Increases with age Maximum incidence after the age } \\
\text { of } 80\end{array}$ \\
\hline Trauma & $\begin{array}{l}\text { Joint fractures and injuries lead to increased risk for } \\
\text { OA }\end{array}$ \\
\hline
\end{tabular}




\begin{tabular}{|l|l|}
\hline Occupation & $\begin{array}{l}\text { Incidence is more in persons doing heavy physical } \\
\text { work like Labourers. }\end{array}$ \\
\hline Exercise & $\begin{array}{l}\text { OA is common in sports persons or those doing } \\
\text { aggressive exercise }\end{array}$ \\
\hline Gender & $\begin{array}{l}\text { Men under the age of 50 Women after the age of } \\
\text { menopause }\end{array}$ \\
\hline Genetics & $\begin{array}{l}\text { Incidence have been found to be increased in children } \\
\text { of parents with early onset OA }\end{array}$ \\
\hline Obesity & Increases the risk of OA \\
\hline Diet & $\begin{array}{l}\text { Increased risk in people with lower vitamin C and D } \\
\text { blood levels }\end{array}$ \\
\hline
\end{tabular}

\section{SAMPRAPTI OF JANU SANDHIGATA VATA:}

In Ayurvedic classics, no direct references for samprapti of januandhigatavata is found. We can consider general Samprapti of Sandhivata - Vatavyadhi for understanding the Samprapti of Januandhigatavata. It is same as that Acharya Charaka has described the Samprapti - Nidana sevana aggravates Vata and the Prakupita Vata gets accumulated in Riktasrotas; i.e., where free space exists for its lodgement and gives rise to generalized and localized diseases. ${ }^{7}$ In the pathogenesis course the patient may develop clinical features of Janusandhigata vata (Osteoarthritis) as follows. When vitiated VataDosha gets Sthana Samshraya in Janusandhi Knee (joint), it causes pain and inflammation in the knee joints and in later stages dislocation and loss of function of the joint of Knee.

Table-3 Showing Pathogenesis (Samprapti Ghataka) of Janusandhigatavata

\begin{tabular}{|l|l|}
\hline Nidana : & Vata Prakopaka Nidana \\
Dosha : & Vata esp. Vyanavayu, Shleshaka Kapha \\
Dushya : & Asthi, Majja, Meda \\
Srotas : & Asthivaha, Majjavaha and / or Medovaha \\
Srotodusti : & Sanga \\
Agni : & Mandagni \\
Dosha Marga : & Marmasthi Sandhi \\
Roga Marga : & Madhyama \\
Udbhavasthana : & Pakvashaya \\
Vyaktasthana : & Asthi - Janusandhi \\
\hline
\end{tabular}

\section{Prognosis:}

Januandhigatavata is one of the Vatavyadhi, so it is Kastasadhya because it occurs in aged people. It is situated in Marma sthana and is Madhyama roga marga, and is Asthi-Majja Dhatu Ashrita.

Table 4 Showing Differential Diagnosis:

\begin{tabular}{|l|l|l|l|l|}
\hline Factors & $\begin{array}{l}\text { Janusandhig } \\
\text { ata } \\
\text { vata }\end{array}$ & Amavata & $\begin{array}{l}\text { Kroshtuka } \\
\text { shirsha }\end{array}$ & Vatarakta \\
\hline Ama & Absent & Present & Absent & Absent \\
\hline Jwara & Absent & Present & Absent & Absent \\
\hline $\begin{array}{l}\text { Hridgoura } \\
\text { va }\end{array}$ & Absent & Present & Absent & Absent \\
\hline Age & Old age & Any age & Any age & Any age \\
\hline Vedana & $\begin{array}{l}\text { During } \\
\text { Prasarana } \\
\text { Akunchana }\end{array}$ & $\begin{array}{l}\text { Vrischikadams } \\
\text { avat Sanchari }\end{array}$ & Teevra & $\begin{array}{l}\text { Mushikada } \\
\text { msavat } \\
\text { peeda }\end{array}$ \\
\hline Shotha & $\begin{array}{l}\text { Vatapurna } \\
\text { Dritisparsha }\end{array}$ & $\begin{array}{l}\text { Sarvashareera, } \\
\text { Sandhigata }\end{array}$ & $\begin{array}{l}\text { Kroustuka } \\
\text { Shirshavat }\end{array}$ & $\begin{array}{l}\text { Mandala } \\
\text { Yukta }\end{array}$ \\
\hline Sandhi & $\begin{array}{l}\text { Weight } \\
\text { bearing - } \\
\text { Knee joint }\end{array}$ & $\begin{array}{l}\text { Small joints to } \\
\text { Big joints }\end{array}$ & $\begin{array}{l}\text { Janu } \\
\text { Pradesha }\end{array}$ & $\begin{array}{l}\text { Small } \\
\text { joints }\end{array}$ \\
\hline Upashaya & Snehana & Rooksha Sweda & $\begin{array}{l}\text { Rakta } \\
\text { Shodhana }\end{array}$ & $\begin{array}{l}\text { Rakta } \\
\text { Shodhana }\end{array}$ \\
\hline
\end{tabular}

\section{Treatment:}

In Ayurveda, the treatment of Janusandhigatavata is aimed at reducing the Vata dosha and to balance the shleshaka kapha so that the joint spaces are adequately lubricated for the free movement of the Knee joints. For this many procedures have been mentioned like snehana, swedana, Mridu Samshodhana, Basti and Vatahara Aushadha prayoga, Ahara and Vihara. In some texts practices of upanaha, agnikarma, bandhana, mardana etc are also described. Different Ghritas, Guggulu, Shallaki preparations are used for Internal medicines. The procedures that were exclusively used as prime therapy in the management of the disease are-

1. Reduction of Weight -Obesity is suggested to be a risk factor for knee osteoarthritis (OA). Excess weight can give burden to the joint and may lead joint damage. 11 pound weight reduction cuts $50 \%$ risk for Osteoarthritis. 5\% weight loss in over weight patients gives $18 \%$ gain in overall function. So weight reduction is very essential for the treatment of Osteoarthritis. Carefully, procedure Udwartana and Lekhana Basti may be carried out after knowing the dosha and dushyas.

2. Basti - Matra Basti ${ }^{8}$ and Tikta Ksheera Basti ${ }^{9}$ relieved the pain and other symptoms significantly. Many studies are conducted on this therapy.

3. Leech Therapy - Symptomatic treatment of osteoarthritis of the knee with leeches is presently undergoing a renaissance. ${ }^{10}$ Leech therapy has wonderful management in pain. New researches have shown that Leech therapy may be an effective treatment for rapid reduction of pain associated with osteoarthritis of the knee.

4. Rasayana - Janusandhigatavata specially occurs in Vriddhavastha due to Dhatukshya. A Rasayana drug nourishes Dhatus and overcomes Dhatukshaya. So it should be used in for the treatment of Sandhigatavata

5. Agni Karma - Agnikarma is effective nonpharmacological, parasurgical procedure for pain management in Sandhigata vata (OA of knee joint)

6. Upanaha Sweda - Sandhigatavata (OA of knee joint) is a type of Vatavyadhi in which upanaha sweda is good one among the treatments. The vatavyadhihara upanaha ${ }^{13}$ is much beneficial in the patient of sandhigatavata (OA knee joint) by relieving the local pain as it contains all Ushnaviryatmak, Tikshna, Vataghna, Vedanasthapana and Shothahara Dravyas."

7. Physiotherapy - OA specially occurs in Old Age. Shortwave diathermy, Ultrasound and Hot pack can be done judiciously, these therapies are add on for Knee $\mathrm{OA}^{15}$. Leech therapy relieves symptoms in patients with osteoarthritis of the knee and is as effective as TENS therapy in the management of osteoarthritis of the knee. ${ }^{16}$

Pathyapathya : Sleshaka kapha kshaya and Vata prakopa due to Vata prakopaka ahara vihara, Dhatu kshava, Sthoulya and Vardhakya have got a major role to play in the manifestation of Janusandhigata Vata. It is a Vatavyadhi which is one among Ashta Maharoga by Vagbhata." The recommended diets are Godhuma (Wheat), Masha (Blackgram), Raktashali (Redrice), Draksha (Grapes), Badara, (Dry Jujube) Madhuka (Sweet), Ushnajala (Hot water), Shritashita jala (Hot and cold water). The Pathya viharas are Atapa Sevana (Sitting in sunlight). Apathya recommending Sandhigata vata are Yava (Barley), Chanaka, Gadarbha Dugdha, Sheetajala (Cold Water), Naveena Madya (New fermentation), Shushka Mamsa (Dry Meat), Jambu. Apathya Vihara mentioned in Sandhigata vata are Chinta (Tension), Ratrijagarana (Waking late night), Vega Sandharana (Holding of natural urges), Chankramana (Walking). ${ }^{18}$

\section{DISCUSSION}

Knee osteoarthritis (OA), which is a degenerative disease, is the most common form of arthritis in the knee. ${ }^{19}$ This systematic review found moderate to strong evidence for the reduction of pain, functional impairment, and joint stiffness through Ayurveda. Whereas the contemporary medical science is more materialistic and having high dependence on the pharmacological interventions. On the otherhand, Ayurveda being a holistic system giving equal importance to physical, mental and spiritual well being. There is vast development in the contemporary field of diagnostic techniques and updated surgical interventions with molecular biology and genetic engineering. But more side effects beyond their benefits. The incidence of chronic and degenerative diseases is much fastly increasing and their effective management is still very far from the reach. In such roadway, the only option remains is the primordial and initial prevention of chronic and non communicable diseases with proper implementation of dietary patterns, good lifestyle and traditional healthy practices.

PREVENTION OF JANU SANDHIGATA VATA (KNEE OSTEOATHRITIS)

The classical symptoms of Sandhigata Vata (OA) are Vata Purna Druti Sparsha (swelling), Prasarana Akunchanayoh Apravritti (difficulty in joint flexion and extension), and Vedana (pain). This disease is more common in both sex and is seen after $4^{\text {th }}$ decade of the life. Ayurveda is for preservation of health and management of the diseased people. ${ }^{20}$ while dealing with the patients it also gives special attention to 
individuals such as Prakriti, Satmya, Sara, Samhanana and etc. ${ }^{21}$ As per Ayurvedic classics, there are three important factors for maintenance of health called as Trayopastambha $a^{22}$ (Three sub pillars of life) a.) Ahara, i.e. right food habits
b.) Swapna, i.e. proper sleep
c.) Brahmacharya i.e.Celibacy

\section{CONCLUSION}

Janusandhigatavata means abnormal Vata residing in the knee resulting in the manifestation of symptoms. The vatavyadhi hara chikitsas like Snehana, upanaha, Basti and Agni karma are much beneficial. Here, pain is one of the chief complaints. So, by using the dravyas with Ushna viryas, Teekshna gunas, Vataghna, Vedanasthapana and Shothahara yield good effects. Leech therapy may be a useful approach in treating this condition as there are no adverse effects. A good-quality RCTs is required for a conclusive judgment of its safety and efficacy. Larger studies and evaluation on patients can prove better management. Thus, this literary review gives a conclusion that Snehana along with swedana would be an ideal treatment for Janusandhigatavata. The quality of life of the patient can be improved by the use of Rasayana and Balya drugs.

\section{ACKNOWLEDGEMENTS}

1. Prof. (Dr.) Arun Kumar Das, Principal, Govt. Ayurvedic College, Balangir, Odisha.

2. Prof. (Dr.) P. K. Panda, Professor \& HOD, P.G Dept. of Roga Nidana, GAC, Balangir.

3. Dr. (Mrs.) Kamini Kar, Principal, SSN Ayurveda College \& Research Institute, Paikmal.

\section{REFERENCES}

1. Agnivesha, Charaka Samhita, Volume-II, Edited by Dr. Brahmanand Tripathi Foreword Agnivesha, Charaka Samhita, Volume-II, Edited by Dr. Brahmanand Tripathi Foreword
by Dr. Prabhakar J. Deshpande, Chaukhamba Surabharati Prakashan Varanasi, Edition2012 p. 942

2. Agnivesha, Charaka Samhita, revised by Charaka and Dridhabala with Ayurveda Dipika Commentary of Chakrapanidatta, edited by Y.T.Acharya, Nirnaya Sagar Press, Bombay, 3rd edition, 1941, Chikitsa Sthana 28/37, Page - 618

3. Agnivesha, Charaka Samhita with Commentary of Chakrapani, Chowkhambha Sanskrit Sansthan, Varanasi 2004 ReprintEdition, pp738, pg 99

4. Charaka Samhita of Agnivesa, Volume-II, Edited by Dr. Brahmanand Tripathi Foreword by Dr. Prabhakar J. Deshpande, Chaukhamba Surabharati Prakashan Varanasi, Edition2012 p 952

5. Sharma R.K. \& Dash Bhagawan, Eng. translation on Charaka Samhita, Chowkhambha Sanskrit Series Office, Varanasi, 2009. Chikitsa Sthana 28/15-17pg no.779

6. Jordan JM, Kingston RS, Lane NE, Nevitt MC et al., Systemic risk factors for osteoarthritis. In Felson DT, conference chair. Osteoarthritis: new insights. Part 1: The Disease and its risk factors. Ann Intern Med. 2000; 133:637-639.

7. Sharma R.K. \& Dash Bhagawan, Eng. translation on Charaka Samhita, Chowkhambha Sanskrit Series Office, Varanasi, 2009.Chikitsa Sthana 28/18 pg no.779.

8. Aman S, Bhattacharyya D. Role of Matra basti in Janu sandhigata vata. International Ayurvedic Medical Journal. 2013;1:1-5.

9. Dattatrya N, Singh JP, Shankar MD. Role of tikta ksheera basti and adityapaka guggulu in the management of sandhigata vata. International Ayurvedic Medical Journal. 2013;1(4):1-6.

10. Andereya S, Stanzel S, Maus U, Mueller-Rath R, Mumme T, Siebert CH, Stock F, Schneider U. Assessment of leech therapy for knee osteoarthritis: a randomized study. Acta Orthop. 2008 Apr;79(2):235-43. doi: 10.1080/17453670710015030. PMID: 18484250 .

11. Michalsen A, Moebus S, Spahn G, Esch T, Langhorst J, Dobos GJ. Leech therapy for symptomatic treatment of knee osteoarthritis: results and implications of a pilot study. Altern Ther Health Med. 2002 Sep-Oct:8(5):84-8. PMID: 12233807.

12. Jethava NG, Dudhamal TS, Gupta SK. Role of Agnikarma in Sandhigata Vata (osteoarthritis of knee joint). Ayu. 2015 Jan-Mar;36(1):23-8. doi: 10.4103/0974(osteoarthritis of knee joint). Ayu. 2015 Jan-Mar;36(1):

13. Dr. Priyanka A. Keram, Dr. Sheetal G. Lodha A CASE REPORT - EFFECT OF VATAVYADHIHAR UPANAHA IN THE MANAGEMENT OF LOCAL PAIN IN JANUSANDHIGATAVATA (O.A. OF KNEE JOINT) International Journal of Scientific-Research, Volume : 6, Issue : 2, February - 2017

14. Kavita Bagalwadi et al: A Comparative Study On Effect Of Koladi Upanaha Sweda And Kushtadi Upanaha Sweda In Janu Sandhigata Vata W.S.R.To Knee Osteoarthritis. International Ayurvedic Medical Journal \{online\} 2019 \{cited September, 2019\}

15. Bansil CK, Joshi JB. Effectiveness of shortwave diathermy and ultrasound in the treatment of osteo-arthritis of the knee joint. Med JZambia. 1975;9(5):138-139

16. Isik M, Ugur M, Yakisan RS, Sari T, Yilmaz N. Comparison of the effectiveness of medicinal leech and TENS therapy in the treatment of primary osteoarthritis of the knee : A randomized controlled trial. Z Rheumatol. 2017 Nov;76(9):798-805. English. doi: 10.1007/s00393-016-0176-1. PMID: 27535276

17. Sri LalchandraVaidya, Hindi translation of Ashtanga Hrudayam, Motilal Banarasidas, New Delhi reprint 1977, Nidana Sthana 8/30; Page -317.

18. Sharma. S, Yalgachin. G, Bhagat. S. Pathya \& apathya in sandhigata vata: a bird seye view. Int J Health Sci Res. 2019; 9(6):309-314.

19. Riis A, Rathleff MS, Jensen MB et al. . Low grading of the severity of knee osteoarthritis pre-operatively is associated with a lower functional level after total knee replacement: a prospective cohort study with 12 months' follow-up. Bone Joint J 2014;96-B:1498-502. 10.1302/0301-620X.96B11.33726

20. Sharma R.K. \& Dash Bhagawan, Eng. translation on Charaka Samhita, Chowkhambha Sanskrit Series Office Sutra Sthana Chapter 30/26Varanasi, 2009. pg no. 585

21. Sharma R.K. \& Dash Bhagawan, Eng. translation on Charaka Samhita Vimana Sthana, Chapter 8/94, Chowkhambha Sanskrit Series Office, Varanasi, 2009 pg no. 771

22. Sharma R.K. \& Dash Bhagawan, Eng. translation on Charaka Samhita Sutra Sthana, Chapter 11/35 Chowkhambha Sanskrit Series Office, Varanasi, 2009 pg no227 